\begin{tabular}{|c|c|c|c|}
\hline Article Info & \multicolumn{2}{|c|}{ RESEARCH ARTICLE | ARAŞTIRMA MAKALESİ } & \\
\hline Title of Article & \multicolumn{2}{|c|}{$\begin{array}{l}\text { The Importance of Accomodation in } \\
\text { Convention Tourism: The Design Criteria } \\
\text { and Spatial Standards of Convention Hotels }\end{array}$} & 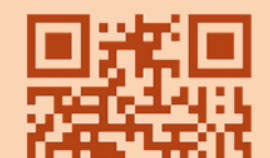 \\
\hline $\begin{array}{l}\text { Corresponding } \\
\text { Author }\end{array}$ & \multicolumn{2}{|c|}{$\begin{array}{l}\text { Sibel POLAT / Bursa Uludağ Üniversitesi, Mimarlık Fakültesi, Mimarlık Bölümü, } \\
\text { sibelpolat@uludag.edu.tr }\end{array}$} & \\
\hline $\begin{array}{l}\text { Received Date } \\
\text { Accepted Date }\end{array}$ & \multicolumn{2}{|l|}{$\begin{array}{l}25.01 .2021 \\
01.03 .2021\end{array}$} & \\
\hline Author / Authors & $\begin{array}{l}\text { Büşra ÖZTAŞ } \\
\text { Sibel POLAT }\end{array}$ & $\begin{array}{l}\text { ORCID: 0000-0003-4882-4458 } \\
\text { ORCID: } 0000-0003-4380-0457\end{array}$ & \\
\hline How to Cite & \multicolumn{2}{|c|}{$\begin{array}{l}\text { Öztaş, B. ve Polat, S. (2021). Kongre Turizminde Konaklamanın Önemi: Kongre } \\
\text { Otelleri Tasarım Kriterleri ve Mekansal Standartları, Kent Akademisi, Volume 14, } \\
\text { Issue 1, Pages, 122-140 }\end{array}$} & $\begin{array}{l}\text { Kent Akademisi } \\
\text { Urban Academy }\end{array}$ \\
\hline
\end{tabular}

\title{
Kongre Turizminde Konaklamanın Önemi: Kongre Otelleri Tasarım Kriterleri ve Mekansal Standartları
}

\begin{abstract}
:
The most preferred venue for convention tourism is convention hotels, which are designed to host national and international meetings and which are the largest of the accommodation facilities. It is seen that the cities which are most preferred for congresses in different countries stand out with qualified convention hotels. Convention hotels should have special design criteria and provide spatial standards to meet the needs of congress participants and to attract more congresses to that city. According to the Turkey Tourism Strategy 2023 Action Plan, it is also necessary to carry out studies about this subject in Bursa which is identified as one of the cities that have appropriate infrastructure for convention tourism. Thus, the aim of this study is to reveal the design criteria and the spatial standards of convention hotels and within this framework to analyze the quality of hotels in which congresses held in Bursa. As a method in the study, literature research, physical assessment of the hotels in Bursa and interviews with related people were conducted. In the case study, the most preferred convention hotels in different countries and the hotels where congresses are mostly held in Bursa were analyzed and compared according to their location, architectural design, spatial organization and
\end{abstract}

${ }^{1}$ M. Arch., Bursa Uludag University, Graduate School of Natural and Applied Sciences, Department of Architecture, busra.abmimarlik@gmail.com ${ }^{2}$ Assoc. Prof., Bursa Uludag University, Faculty of Architecture, Department of Architecture, sibelpolat@uludag.edu.tr 
spatial standards.. As a result, it was seen that hotels in Bursa did not meet the design criteria and spatial standards in the current literature. Thus, a recommendation list were developed for convention hotel design to contribute to design of new convention hotels for developing convention tourism in Bursa.

KEYWORDS: convention tourism, convention hotel, convention hotel design criteria and standards, Bursa

\section{ÖZ:}

Kongre turizminde en çok tercih edilen mekan türü, ulusal ve uluslararası toplantılara ev sahipliği yapmak üzere tasarlanan, konaklama tesisleri içinde en büyük olan kongre otelleridir. Farklı ülkelerde en fazla kongre yapılan şehirlerin nitelikli kongre otelleriyle öne çıktığı görülmektedir. Kongre katılımcılarının işlevsel gereksinimlerini karşılayabilmek ve ilgili şehre daha çok kongre çekebilmek için kongre otellerinin belirli tasarım kriterlerine ve mekansal standartlara uygun olarak tasarlanması gerekmektedir. Türkiye Turizm Stratejisi 2023 Eylem Planı'na göre, kongre turizmine altyapısı uygun illerden biri olarak belirlenen Bursa'da da bu konuda çalışmalar yapılması gerekmektedir. Bu noktada çalışmanın amacı; ilgili literatür üzerinden kongre otellerinin tasarım kriterlerini ve mekansal standartlarını ortaya koyarak, bu bağlamda Bursa' da kongre yapılan otellerin yeterliliğini analiz etmektir. Çalışmada yöntem olarak, literatür araştırması, Bursa'daki otellerle ilgili yerinde fiziksel tespitler ve yetkililerle görüşmeler yapılmıştır. Alan çalışmasında, farklı ülkelerde en çok tercih edilen kongre otelleriyle, Bursa'da en fazla kongre yapılan oteller konum, mimari tasarım, mekansal kurgu özellikleri ve mekansal standartlar açısından analiz edilerek, karşılaştırılmıştır. Çalışma sonucunda, Bursa'da kongre yapılan otellerin gerekli tasarım kriterlerini ve mekansal standartları sağlamadığı görülmüştür. Yapılan çalışmanın yeni kongre otellerinin tasarımında mimarlara rehberlik edeceği ve Bursa' da kongre turizminin gelişmesine katkı koyacağı düşünülmektedir.

ANAHTAR KELIMELER: kongre turizmi, kongre oteli, kongre oteli tasarım kriterleri ve standartlar1, Bursa

\section{Kongre Turizminde Konaklamanın Önemi: Kongre Otelleri Tasarım Kriterleri ve Mekansal Standartları}

\section{GíRiș:}

Türkiye, 1980’li yıllarda turizm sektöründe başlattığı yatırım hamleleriyle ve sahip olduğu değerleriyle hızla gelişerek, 2000'li yıllarda dünya turizminde söz sahibi ülkeler arasına girmiştir (Anonim 2014). 2007 yılında Kültür ve Turizm Bakanlığı, uluslararası pazarda turist sayısı ve turizm geliri bakımından Türkiye'nin 2023 yılına kadar ilk beş ülke arasında önemli bir varış noktası ve uluslararası bir marka haline gelmesi vizyonuyla Turizm Stratejisi 2023 Eylem Planını hazırlamıştır. Plan kapsamında turizmin çeşitlendirilmesi stratejisi doğrultusunda kongre ve fuar turizminin de geliştirilmesi hedeflenmiş, İstanbul, Ankara, Antalya, İzmir, Konya, Bursa ve Mersin kongre turizmi açısından altyapısı uygun iller olarak tanımlanmış, bu illerde Kültür ve Turizm Bakanlığı tarafından yönlendirici çalışmalar yapılacağı ifade edilmiştir (Anonim 2017).

Türkiye'de en fazla kongre yapılan şehirler içinde beşinci sırada olan (TÜRSAB 2008) ve kongre turizminin geliştirilmesi hedeflenen şehirlerden biri olan Bursa, doğal ve kültürel miras değerleri, termal ve kış turizmi imkânları ile yüksek bir turizm potansiyeline sahiptir. 2020 Yılı 1/100.000 Ölçekli Bursa Çevre Düzeni Planı amacında da şehrin turizm kimliğinin korunmasına ve geliştirilmesine vurgu yapılmıştır (Anonim 1998). Bursa'da kongre turizminin geliştirilmesi hem sahip olduğu değerlerin sürdürülebilir olarak kullanılması ve tanıtılması, hem de şehrin ekonomik, sosyal ve fiziksel anlamda gelişmesi için büyük önem taşımaktadır.

Yapılan araştırmalara göre, kongre turizminin ekonomik açıdan otuz yedi sektör üzerinde doğrudan etkisi olduğu vurgulanmıştır. Kongre katılımcılarının, etkinlik sırasında konaklama, ulaşım, yiyecek, içecek, tatil alanlarından; eğlence, spor, sanatsal gösterilere; ev kiralamadan, iletişim, tercümanlık ve bilişim hizmetlerine, eğitim ve kariyer geliştirme programlarına kadar birçok sektör ile ilişki içerisinde olduğu ve pek çok alanda istihdam sağladığı ifade edilmektedir (Arber 2008). Ayrıca kongrelerin belirli dönemlerde değil, tüm yıl boyunca yapılan faaliyetler olması, turizmi sezonluk olmaktan çıkartarak elde edilen gelirin sürekli olmasını sağlar. Üstelik kongre turizminde turist başına düşen gelir miktarı, diğer turizm türlerindeki turist başına düşen gelir miktarının üç katı kadardır (Aymankuy 2006). 
Bunlara ek olarak, kongre turizminin fiziksel açıdan şehirlerde kaliteli konaklama yapılarının ve toplantı mekanlarının inşa edilmesini, haberleşme, güvenlik, ulaşım açılarından yeterli altyapı tesislerinin oluşturulmasını, tarihi ve kültürel eserlerin restorasyonlarının ve bakımlarının daha kısa zamanda ve özenli yapılmasını sağladığı ifade edilmektedir. Ayrıca katılımcıların gittikleri yerlerde alışveriş ve geziler sırasında sosyal-kültürel etkileşim ortamının gelişmesini sağladıkları, şehrin uluslararası imajını güçlendirdikleri belirtilmektedir (Aymankuy 2003).

Kongrelerin \%44'ü kongre otellerinde gerçekleştiğinden, kongre turizminin geliştirilmesinde kongre otelleri önemli bir yere sahiptir (Anonim 2017a). Yapılan bir ankette, bir kongre şehrini diğerinden daha cazip hale getiren faktörlerden en önemlisinin otel seçimi ve konaklama imkânları olduğu tespit edilmiştir (Var ve ark. 1985). Kongre otellerinin tercih noktasında şehirdeki ulaşılabilirlik, konaklama tesislerinin yeterliliği, toplantı salonlarının niteliği ve sosyal program düzenlenebilecek özellikli mekanların olması büyük etkendir. Ayrıca kongre sırasında katılımcılar 24 saatlerini otelde geçirdiklerinden, iyi işleyen bir kongre salonuna, konforlu otel odalarına ve işlevsel genel mekanlara daha fazla gereksinim duymaktadır. Bu bağlamda bir şehre kongre çekebilmek için öncelikle şehirde kongre turizmini destekleyen mevcut konaklama tesislerinin yeterliliğinin incelenmesi, sonrasında yeni yapılacak kongre otellerinin konaklayanların beklentilerini ve işlevsel gereksinimlerini optimum düzeyde karşılayacak şekilde tasarlanması için temel kriterlerin tanımlanması gerektiği düşünülmektedir (Öztaş 2019). Bu gereksinimler kongre otelleri tasarımı konusunda güncel çalışmaların yapılmasını gerektirmektedir. Oteller ile ilgili birçok araştırma ve çalışma yapılmasına karşın yapılan literatür araştırmalarında kongre otelleri üzerine yapılan çalışmaların yetersiz olduğu ve kongre otellerinin tasarım, program ve mekansal kurgu bağlamında bütüncül olarak ele alınmadığ görülmüştür. Bu çerçevede çalışmada incelenen hipotezler şunlardır:

1. Kongre otelleri işlevsel ve mekansal açıdan özel tasarım kriterlerine ve standartlarına sahiptir.

2. Bursa'da kongre oteli eksikliği vardır ve mevcut oteller kongre işlevini yeterince sağlayamamaktadır.

3. Yurtdışında en çok tercih edilen kongre otelleri gerekli tasarım kriterlerini ve mekansal standartları sağlamaktadır.

Çalışmada öncelikle kongre otellerinin mimari özellikleri derlenmiş, alan çalışması kapsamında Amerika, Avrupa, Asya Pasifik kıtalarındaki ülkelerden dokuz kongre oteli ile Türkiye'den İstanbul'da en çok kongre yapılan bir, Bursa'da iki otel olmak üzere toplam on iki otel analiz edilmiştir. Ayrıca Bursa' da kongre turizmi konusundaki sorunları ve beklentileri tespit etmek için Bursa'da kongre düzenleme konusunda yetkin bir firma olan Burkon Turizm \& Kongre Şirketi genel müdürüyle görüşmeler yapılmıştır. Sonuç olarak kongre oteli tasarımı için bir öneriler seti oluşturulmuştur. Yapılan çalışmanın kongre oteli tasarlayacak mimarlara, tasarımcılara, yatırımcılara ve girişimcilere yol göstereceği düşünülmektedir.

\section{Kongre Otellerinin Mimari Özellikleri}

Kongre otelleri; konferanslar, toplantılar, eğitim programları için etkili bir ortam sağlamak üzere özel olarak tasarlanmış konaklama tesisleri olarak tanımlamaktadır (Penner 1991). Çalışma kapsamında kongre otellerinin konum, mimari tasarım, mekansal kurgu ve mekansal standartlar açısından hangi niteliklere sahip olması gerektiği incelenmiştir.

Konum açısından kongre otellerinin dört mevsim turizme destek vereceği düşünülerek şehirlerarası ve şehir içi ulaşım olanakları yüksek (Aymankuy 2006), şehir merkezindeki bölgelerde yer alması gerektiği belirtilmiştir. Otelin konumuna karar verilirken dikkat edilmesi gereken diğer unsurlar; arazi özellikleri (eğim, peyzaj, manzara), çevresel faktörler (rekreasyon alanlarına, şehrin çalışma ve ticari bölgelerine, eğlence merkezlerine yakınlık) ve güvenliktir (Karasu 1985; Yürek 2007; Penner ve ark. 2013).

Mimari tasarım açısından kongre otellerinin bulundukları şehirde/bölgede simgesel bir öğe olarak tasarlanması, kütlesel form açısından farklı geometrik biçimlere (lineer, U, L, noktasal, kare, karma düzen, üçgen, daire) sahip olabilecekleri, ancak kongre mekanı ile yatak katlarının ayrı olarak çözümlenmesi gerektiği önerilmiştir. Yatak katları dikdörtgen, kule ve atriyumlu olarak düzenlenebileceği gibi, çift taraflı kullanımın oda sayısını arttıracağı belirtilmiştir (Rutes ve Penner 1985; Lawson 2000).

Mekansal kurgu açısından kongre otellerinde mekanlar işlevlerine ve ilişkilerine göre girişler, genel mekanlar, konaklama mekanları, kongre mekanları, hizmet mekanları, teknik mekanlar, dış mekanlar şeklinde gruplanmıştır (Peters ve Erben 1979; Lawson 1995; Lawson 2000). Kongre otellerinde, kongre mekanı ve otel kullanımı ayrı olarak da yapılabileceği için iki ayrı giriş planlanmalı, tüm girişlere araçla ulaşım sağlanmalı ve kullanıcılar otel dışından veya içinden kongre mekanlarına rahatça ulaşabilmelidir (Penner ve ark. 2013). Ana genel mekanlar, lobi, yemek, eğlenme

The Importance of Accomodation in Convention Tourism: The Design Criteria and Spatial Standards of Convention Hotels

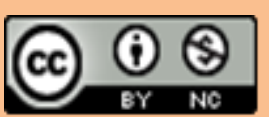


ve spor - spa bölümü olarak belirtilmiştir. Oteldeki tüm mekanlara lobiden dağılım olmalıdır. Bu sebeple lobideki çekirdek (merdiven-asansör-1slak hacim) yeri çok önemlidir. Konaklama mekanları (yatak katları) genellikle genel mekanların üst katına konumlandırılır. Oda büyüklüklerini, tiplerini çeşitlendirmek, suit oda, kral dairesi gibi farklı odalar tasarlamak o otelin tercih şansını artıracaktır. Kongre salonları, ulusal ve uluslararası olmak üzere, geniş katılımlı faaliyetlerin gerçekleştirildiği salonlardır. Bu nedenle otellerin kongre mekanlarında balo salonunun ve kongre salonunun ayrı olarak tasarlanması da katılımcı sayısı göz önüne alındığında önemli bir noktadır. Kongre salonu dışında, seminerler, küçük ölçekli toplantılar için yeterli sayıda toplantı salonu, etkinlikler için çalıştay salonu, sergi salonu ve katılımcıların boş vakitlerini geçirmesi için dinlenme salonu, çalışma alanı tasarlanmalıdır. İç mimari ve planlama basit ve akıcı olmalı, teknolojik bağlantıların sağlanmasına önem verilmelidir (Pembegül 2009). Literatür araştırmasında kongre mekanlarının tasarımında erişim kolaylığı, kompaktlık, düzenlilik - netlik, mekansal zenginlik, karma işlevlilik, okunabilirlik, esneklik kavramlarının önem kazandığı görülmüştür (Penner ve ark. 2013; Öztaş 2019). Bunların tanımları ve nasıl sağlanabileceği aşağıdaki gibi özetlenebilir:

- Erişilebilirlik: Kullanıcıların otel dişından veya içinden kongre mekanlarına rahatça ulaşabilmesi. Kongre mekanlarına içeriden erişim için yeterli sayıda ve büyüklükte yatay ve düşey sirkülasyon elemanlarının olması. Otelin ana girişinin yanında, kongre mekanlarına dışarıdan erişim için ayrı bir girişin olması.

- Kompaktlık: Kongre mekanlarının otel içinde belli bir alanda toplanması. Kongre mekanlarının yatayda ve düşeyde birbiriyle yakın ve direkt ilişkili olacak şekilde organize edilmesi. Kongre mekanları farklı katlarda ise bu mekanların gerekli sirkülasyon sistemleriyle birbirine güçlü bir şekilde bağlanması.

- Düzenlilik: Kongre mekanlarında biçimsel açıdan kullanılamayacak alanlar oluşturulmaması.

- Mekansal zenginlik: Kongre mekanlarının hem kendi içinde/otelin diğer kısımlarıyla, hem de otel dışındaki peyzajla veya manzarayla görsel ilişki kurabilmesi. Otelde peyzaj/manzara yönünde şeffaf cepheler tasarlanması, kongre mekanlarının fuayelerinin peyzaj ve manzarayla ilişkilendirilmesi.

- Karma işlevlilik: Kongre mekanlarında aynı anda veya farklı zamanlarda çeşitli etkinliklerin yapılabilmesi. Farklı büyüklükte/yükseklikte salonların ve fuayelerin tasarlanması.

- Okunabilirlik: Kongre mekanlarının hem dışarıdan görsel olarak algılanabilmesi ve girişinin rahatça görülebilmesi, hem de mekanlara içeriden kolayca erişilebilmesi ve mekanlar arasında rahatça yön bulunabilmesi. Otelin içinde galeriler tasarlanarak kongre mekanlarının kullanıcılara gösterilmesi.

- Esneklik: Kongre mekanlarının zamanla ihtiyaç duyulan yeni gereksinimlere cevap verebilmesi, aynı veya farklı zamanlarda çeşitli düzenlemelerle farklı işlevler için kullanılabilmesi. Salonların ihtiyaç halinde bölünebilmesi için bölme sistemlerine ve farklı mobilyalarla düzenlenme olanaklarına sahip olması. İhtiyaç halinde salonların kat yüksekliklerinin ayarlanabilmesi (Öztaş 2019).

Bunlara ek olarak literatürde kongre otellerindeki genel mekanlarda, konaklama mekanlarında, kongre mekanlarında ve teknik mekanlarda sağlanması gereken mekansal standartlar olduğu görülmüştür (Tablo 1). Böylece kongre otellerinin işlevsel açıdan özel tasarım kriterlerine ve standartlarına sahip olması gerektiğiyle ilgili birinci hipotez doğrulanmıştır. Alan çalışması kapsamında bu bölümde derlenen ve geliştirilen kongre otelleri tasarım kriterleri ve standartları çerçevesinde dünyada en çok tercih edilen kongre otelleri ile Bursa'da en çok kongre yapılan oteller analiz edilmiştir. 
Tablo 1. Kongre oteli mekansal standartlar tablosu (Doğu 1982; Balıkçığlu 2004; Gökdağ Aydıncı 2009; Opak 2009)

\begin{tabular}{|c|c|c|c|}
\hline \multicolumn{4}{|c|}{ Mekansal Standartlar } \\
\hline Ana Mekanlar & $\begin{array}{l}\text { Alt Mekanlar / } \\
\text { Mimari Elemanlar }\end{array}$ & Referans & Açıklama \\
\hline \multirow{9}{*}{$\begin{array}{l}\text { Genel } \\
\text { Mekanlar }\end{array}$} & Lobi & $\begin{array}{l}\text { otel müşteri sayısının min. } \\
\% 25\end{array}$ & $\begin{array}{l}\text { referans değer kadar ihtiyaca cevap } \\
\text { vermeli }\end{array}$ \\
\hline & Merdivenler & 3 tür merdiven & müşteri, servis ve yangın merdiveni \\
\hline & Asansörler & 2 tür asansör & $\begin{array}{l}\text { servis ve müşteri asansörü, } \\
\text { asansörden sonra en uzak mesafe } 60 \\
\text { m, optimum mesafe } 45 \mathrm{~m}\end{array}$ \\
\hline & Asansör Lobisi & $\begin{array}{l}\text { koridorların min. } 3 \text { katı } \\
\text { büyüklüğ̈ünde }\end{array}$ & $\begin{array}{l}\text { bekleme alanı olarak kullanıldığı } \\
\text { için yeterli büyüklükte olmalı }\end{array}$ \\
\hline & Kapilar & genişlikleri min. $2,2 \mathrm{~m}$ & ortak alanlardaki kapılar \\
\hline & Koridorlar & genişlikleri min. $2,7 \mathrm{~m}$ & servis alanı yoksa min. $2,2 \mathrm{~m}$ \\
\hline & Vestiyer & kişi başı $0,1 \mathrm{~m}^{2}$ & kongre katılımcı sayısı baz alınmalı \\
\hline & Restoranlar, barlar & $\begin{array}{l}\text { oda sayısının 3/4'ü kadar } \\
\text { olmalı }\end{array}$ & oda sayısıyla orantılı olmalı \\
\hline & Yatak katları & 1 Oda için $85 \mathrm{~m}^{2}$ & $\begin{array}{l}\text { konaklama, yeme-içme, dinlenme, } \\
\text { rekreasyon alanları dâhil }\end{array}$ \\
\hline $\begin{array}{l}\text { Konaklama } \\
\text { Mekanları }\end{array}$ & Kongre mekanları & kişi başı $6,6 \mathrm{~m}^{2}$ & $\begin{array}{l}\text { kongre salonları, toplantı odaları, } \\
\text { sergi alanları, çalışma odaları dâhil }\end{array}$ \\
\hline \multirow{6}{*}{$\begin{array}{l}\text { Kongre } \\
\text { Mekanları }\end{array}$} & Kongre salonları & $\begin{array}{l}1000 \text { oda için min. } 36 * 76 \mathrm{~m} \\
\text { büyüklüğünde salon }\end{array}$ & yaklaşık $3000 \mathrm{~m}^{2}$ olmalı \\
\hline & Kongre salonları & $\begin{array}{l}\text { tavan } \mathrm{h}=\min .4,9 \mathrm{~m} \\
\text { salon alan1 }>1400 \mathrm{~m}^{2} \text { ise } \\
\mathrm{h}=6,1 \mathrm{~m}\end{array}$ & $\begin{array}{l}\text { kongre salonu alanı ve tavan } \\
\text { yüksekliği arasındaki } \\
\text { kurulmalı }\end{array}$ \\
\hline & $\begin{array}{l}\text { Ana kongre salonu } \\
\text { fuayesi }\end{array}$ & ana salonun 0,3 ile $0,4 \mathrm{~m}^{2}$ & min. değer baz alınmalı \\
\hline & Fuaye & kişi başına 0,3 ile $0,5 \mathrm{~m}^{2}$ & her kongre salonunun fuayesi olmalı \\
\hline & Toplantı salonu & $\begin{array}{l}\text { koltuk başına } 0,9 \mathrm{~m}^{2} \\
\text { banket düzeninde } 1,1 \mathrm{~m}^{2}\end{array}$ & tavan yüksekliği en az 3,3 m olmalı \\
\hline & Mutfak & restoran alanının $\% 50-60{ }_{1}$ & restoran alanıyla orantılı olmalı \\
\hline
\end{tabular}




\begin{tabular}{|l|l|l|l|}
\hline & Otopark & $\begin{array}{l}\text { oda sayısının \%25'i kadar } \\
\text { otopark alanı }\end{array}$ & $\begin{array}{l}\text { mutlaka kendi bünyesinde otopark } \\
\text { planlanmalı }\end{array}$ \\
\hline $\begin{array}{l}\text { Teknik } \\
\text { Mekanlar }\end{array}$ & Otopark & araç başına $32,5 \mathrm{~m}^{2}$ alan & koridor ve rampalar dahil \\
\cline { 2 - 4 } & Vale parkı & araç başına $18,5 \mathrm{~m}^{2}$ lik alan & min. değer baz alınmalı \\
\hline
\end{tabular}

\section{Araştırmanın Yöntemi}

Dünya kongre pazarındaki tüm gelişmeler Uluslararası Kongre ve Toplantı Birliği (ICCA- International Congress and Convention Association) ile Uluslararası Kongre Büroları Birliği (ICVB) tarafından takip edilmektedir. Bu kuruluşlar, her yıl organize edilen kongre ve toplantıların dökümü, kongre ve konferanslarla ilgili bilgiler ve haber bültenleri gibi hizmetler vermektedir. En fazla uluslararası kongre düzenlenen ilk beş ülke Amerika, Almanya, Birleşik Krallık, İspanya, İtalya'dır. İlk beş şehir ise Barcelona, Paris, Viyana, Berlin, Londra'dır.

Makalede dünyada en çok tercih edilen kongre şehirleri için ICCA'nın ve en iyi kongre otelleri için Cvent'in (Event Management Software \& Hospitality Solutions- Etkinlik Yönetimi Yazılımı ve Konaklama Çözümleri) verilerinden faydalanılmıştır. Oteller ICCA'nın 2017 yılı listesinden bulundukları kıtada en çok kongre yapılan ülke ve şehirler arasından ve Cvent'in listesinden bu ülke ve şehirlerdeki en çok tercih edilen kongre otelleriyle çakıştırılarak seçilmiştir. ICCA'nın kongre otelleri üyeliğine dâhil ettiği otellerin taşıması gereken özellikler; en az dört toplantı odasına ve en az 150 yatak odasına sahip olması ve kongre salonlarının tiyatro düzeninde en az 150 kişi kapasiteli olmasıdır (ICCA 2017). Ayrıca incelenen otellerin 2000 yılı sonrası yapılmış olmasına dikkat edilmiştir. Sadece Avrupa kıtasında, Prag'daki Hilton Prag Hotel, 1991 yılında yapılmış ancak 2006 yılında renovasyon geçirmiş ve Cvent (Event Management Software \& Hospitality Solutions)'in Avrupa kongre otelleri sıralamasında ilk 50 otelde 1. sirada olduğu için seçilmiştir. Türkiye'deki otellerin seçiminde ICCA'nın verileri ve Burkon Turizm \& Kongre Şirketinin genel müdürüyle yapılan görüşmeler temel alınmıştır. ICCA Asya-Avrupa listesinde İstanbul en fazla kongre yapılan şehir olduğu için İstanbul'dan bir otel seçilmiştir. Bursa'dan seçilen her iki otel de kongre oteli olarak tasarlanmamış olmakla birlikte, şehirde en fazla kongre yapılan oteller bunlar oldukları için incelenmişlerdir (Eker 2019). Çalışma için seçilen kongre otelleri şunlardır:

- Amerika otelleri

JW Marriott Hotel Indianapolis (1. sıradaki ülke, 73. sıradaki şehir, 79. sıradaki otel)

Omni Nashville Hotel (1. siradaki ülke, 1. sıradaki otel)

Hilton Americas - Houston Hotel (1. sıradaki ülke, 32. sıradaki şehir, 17. sıradaki otel)

- Avrupa otelleri

Hilton Prag Hotel (14. sıradaki ülke, 7. sıradaki şehir, 1. sıradaki otel)

Mövenpick Hotel Amsterdam City Center (6. sıradaki ülke, 12. sıradaki şehir, 9. sıradaki otel)

Madrid Marriott Auditorium Hotel \& Conference Center (3. sıradaki ülke, 6. sıradaki şehir, 13. sıradaki otel)

- Asya pasifik otelleri

Marina Bay Sands Hotel (7. sıradaki ülke, 1. sıradaki şehir, 10. sıradaki otel)

Bangkok Marriott Marquis Queen's Park Hotel (6. sıradaki ülke, 4. sıradaki şehir, 11. sıradaki otel)

Seoul Dragon City Hotelplex (3. sıradaki ülke, 2. sıradaki şehir, 50. sıradaki otel)

- Türkiye otelleri

Crowne Plaza Bursa Hotel (Türkiye'de 5. sıradaki şehir) (TÜRSAB 2008)

Hilton Bursa Convention Center and Spa (Türkiye'de 5. sıradaki şehir) (TÜRSAB 2008)

Hilton İstanbul Bomonti Hotel \& Conference Center ( Türkiye'de 1. sıradaki şehir, dünyada en çok kongre yapılan 133. sıradaki şehir) (ICCA 2017)

Otel örnekleri; web sitelerindeki bilgiler ve daha önce bu otellerle ilgili yapılmış çalışmalar temel alınarak konumları, mimari tasarım ve mekansal kurgu özellikleri ile mekansal standartları açısından analiz edilmiş, toplam 12 otel birbirleriyle karşılaştırılmıştır. Türkiye'deki oteller ziyaret edilerek, yerinde fiziksel tespitler yapılmıştır. Bunlara ek olarak Bursa'da kongre turizmi konusundaki sorunları ve beklentileri tespit etmek için Burkon Turizm \& Kongre şirketinin genel müdürüyle görüşmeler yapılarak değerlendirmelerde bulunulmuştur. 


\section{Bulgular}

\subsection{Görüşmelerin Değerlendirilmesi}

2000 yılında Bursa'da turizm sektörünün gelişmesini sağlamak, topluma ve çalışanlara faydalı olmak misyonuyla kurulan Burkon Turizm \& Kongre Şirketi Bursa'da kurulduğundan beri düzenlediği 223 kongre ile öne çıkan bir şirkettir. Çalışma kapsamında Burkon Turizm \& Kongre Şirketi genel müdürü Hasan Eker ile Bursa'da kongre turizminin mevcut durumunu değerlendirmek üzere 2016 ve 2019 yıllarında iki görüşme yapılmıştır. Bu görüşmelerde Bursa'da turizm sektörünün mevcut durumu, Bursa'nın neden bir turizm şehri olamadığı, Bursa'yı turizm şehri yapacak değerlerin neler olduğu, Bursa'nın kongre turizmindeki yeri, Bursa'nın kongre turizmine hizmet eden mekanları, Bursa'nın kongre oteline ihtiyacı olup olmadığı, bir kongre otelinde olması gereken özellikler sorulmuştur.

Görüşmelerde, Bursa'nın Türkiye'ye gelen turistlerin \%1,5'luk kısmını ağırladığı, yazın Arap turistlerin, diğer mevsimlerde de daha çok iş /sanayi amaçlı turistlerin geldiği, ayrıca Uludağ'ın ocak, şubat aylarında kış turizmine, mart ayında da kongre turizmine hizmet ettiği, turist sayısı olarak yaklaşık 3000 kişinin Uludağ, 3000 kişinin şehir merkezine gittiği ifade edilmiştir.

Bursa'nın bugüne kadar yeterli yatırımı yapmadığı ve planlı olarak çalışmadığı için bir turizm şehri olamadığı, bir yerin turizm şehri olabilmesinde konaklama, altyapı, ulaşım ve eğlence yatırımlarının önemli olduğu, Bursa'nın altyapı ve konaklama bakımından iyi durumda olduğunu belirtilmiş, ancak eğlence yatırımlarına ve ulaşıma daha çok ağırlık verilmesi gerektiği vurgulanmıştır. Bursa'nın uzun vadeli ve profesyonel şekilde tanıtımının yapılması ve bunun yanında yeterli kongre sektörü çalışanına ve kongre altyapısına sahip olunması için çalışmalar yapılması gerektiği belirtilmiştir.

Ayrıca şehirlere göre kongre maliyetinin değiştiği, örneğin Bursa'nın Antalya'ya göre bu konuda daha pahalı olduğu, Bursa'da otele, sabah kahvaltısına, akşam yemeğine, kongre salonuna, odaya ayrı ücret ödendiği, ancak Antalya'da otel odası alındığı zaman kongre salonu, içecek (çay, kahve) ve yiyecek (sabah kahvaltısı, akşam yemeği) ücreti ödenmediği belirtilmiştir.

Bursa'da kongre turizminin, Merinos Atatürk Kongre Kültür Merkezi'nde ve daha çok 5 yıldızlı otellerde yapıldığı, en fazla sağlık ve mühendislik alanlarında yılda yaklaşık yirmi-yirmi beş tane kongrenin yapıldığı ifade edilmiştir. Bursa'nın en fazla 1000 kişilik kongre kapasitesine sahip olduğu, Merinos AKKM'nin iki büyük salonuyla bu ihtiyacı karşıladığı, üçüncü büyük salonun 200 kişilik, son derece basık, biçimsiz olduğu belirtilmiştir. Halbuki büyük kongrelerde katılımcıların genellikle ilk günden sonra paralel oturumlar için beş-altı tane salona dağıldıkları, Bursa'da bunu sağlayacak bir tesisin olmadığı, Bursa'nın daha büyük ve altı-yedi salonlu kongre tesisine ihtiyacı olduğu söylenmiştir.

Bursa'da kongre oteli olmadı̆̆ , ama en fazla kongre yapılan otellerin, Crowne Plaza Bursa Hotel ve Hilton Bursa Convention Center and Spa olduğu belirtilmiştir. Tercih nedeni olarak salon sayılarının fazlalığı ve fuaye alanlarının büyük olması gösterilmiştir. Ayrıca İstanbul'da Hilton İstanbul Bomonti Hotel \& Conference Center'ın da kongre oteli olarak çok tercih edildiği ve başarılı bulunduğu belirtilmiş̧ir.

Bursa'da nitelikli kongre otellerine ihtiyaç olduğu belirtilmiş, kongre katılımcılarının boş zamanlarında şehri gezebilmeleri için kongre otellerinin öncelikle şehir merkezine yakın olması ve etrafında da her gelir grubuna hitap edecek uygun fiyatlı otellerin yer alması gerektiği ifade edilmiştir. Kongre otellerinin sahip olması gereken özelliklerde; toplantı salonu kapasitesinin önemli olduğu, kongrelerin genellikle 500 kişi ile 1000 kişi arasında katılımcı içerdiği, 1000 kişilik bir kongre yapmak için en az üç adet 300 kişilik salon, bir tane 800 kişilik salon ve en az $500 \mathrm{~m}^{2}$ bir fuaye, en az bir tane de workshop salonuna ihtiyaç olduğu, 1000 kişiye uygun restoran, uygun bir lobi, kokteyl alanı olması gerektiği belirtilmiştir. Kongrelerin masraflarının genellikle stant açan firmalar tarafından karşılandı̆̆ı, bu nedenle stant alanlarına ihtiyaç duyulduğu, genellikle fuayelerin stant alanları, bildiri ve poster alanları olarak kullanıldığı, bu nedenle merdivenin fuayeyi bölmemesinin önemli olduğu vurgulanmıştır. İnsanların salonlar arasında yönlenmesinin, salonları bulmasının kolay olması, otelin kompakt bir yapıda olması, kongre ve otel konuklarının girişlerinin ayrı olarak yapılmasının otelin kullanımı açısından rahatlıklar sağladığı belirtilmiştir. Kongre otellerinde en az 250 oda olması gerektiği, katılımcıların genellikle tek kişilik odaları tercih ettiği, bu nedenle kongre pazarında yatak sayısından çok oda sayısının önemli olduğu bildirilmiştir (Eker 2016, 2019). 


\subsection{Konum Özelliklerinin Değerlendirilmesi}

$\mathrm{Bu}$ çalışmada analiz edilen otel konumlarını incelediğimizde öncelikle şehir merkezindeki otellerin, ayrıca havaalanına maksimum yirmi km uzaklıkta olan otellerin daha çok tercih edildiği görülmüştür. On iki otelin tamamında şehir içi ulaşım kolaylığı bulunmaktadır. Çevrelerindeki yapılar, işlevler yönünden zengin ve çok çeşitlidir. Otellerin büyük çoğunluğu şehir merkezinde konumlandığı için, şehir manzarasına hâkim oteller, dağ, deniz, nehir manzarasına hâkim otellere göre daha çoktur. Bursa'daki otellere baktığımızda, Crown Plaza Nilüfer ilçesinde yeni gelişen bir alt merkezde, Hilton Bursa'nın Osmangazi ilçesinde, Yalova yolu üzerinde yer almaktadır. İki otelde de havayoluyla ulaşım İstanbul'daki Sabiha Gökçen Havalimanından yapılabilir. Hilton'un şehirlerarası otobüs terminaline uzaklı̆ğ beş km civarındadır ve metro hattı önünden geçmektedir. Crown Plaza'nın terminale uzaklığı yaklaşık on üç km, metro hattına uzaklığı iki buçuk km civarındadır. Her ikisi de şehir ve dağ manzarasına sahiptir, Crown Plaza'nın yakınında iş merkezleri, AVM, hastane, park, stadyum gibi işlevler, Hilton'un çevresinde iş merkezleri, AVM, fuar ve kongre merkezi, botanik park ve hayvanat bahçesi, bilim ve teknoloji merkezi gibi işlevler yer almaktadır. Bu noktada her iki otelde konum açısından Bursa'da olumlu özelliklere sahiptir, ancak Hilton, şehirlerarası otobüs terminali ve metro bağlantısı ile daha avantajlıdır.

\subsection{Mimari Tasarım Özelliklerinin Değerlendirilmesi}

Otellerin mimari tasarım özellikleri, bulunduğu ülkeye, şehre, onların sahip olduğu sosyal ve kültürel yapıya göre farklılıklar gösterir. İncelenen otellerin tamamında yenilikçi tasarım yaklaşımları ve yapım teknikleri görülmüştür. Şehirde dikkat çekici ve ikonik bir yapı olmaya çalışılırken, otellerin bulunduğu konum ve manzara özellikleri tasarımda ön planda tutulan kriterler arasında olmuştur.

Otellerde mimari tasarıma başlarken öncelikle mimari kütle formuna ve yatak katları plan tipolojisine karar verilir. Kütlenin geometrisi otelin biçimsel karakterini belirler (Yetiz Özden 2015). Seçilen otellerin mimari kütle formları incelendiğinde toplam on iki otel arasından sekiz otel lineer düzendedir. Otellerin yatak katları plan tipleri incelendiğinde altı otel dikdörtgen formlu diğer altı otel L, atrium, $\mathrm{U}$ ve üçgen formlu yatak katlarından oluşmaktadır. Ayrıca otellerin tamamında koridorun çift tarafı oda olacak şekilde tasarlanmıştır. Yerleşim planları açısından, kongre mekanı ile konaklama mekanlarının aynı yapı içerisinde olması, kongre mekanının podyum tabanda (alt katlarda) olması tercih edilmektedir. Konaklama mekanlarının da kule olarak tasarlandığı görülmektedir (Tablo 2). Bursa'daki otellere mimari tasarım açısından baktı̆̆ımızda, Crown Plaza yalın çizgilere sahiptir ve podyum tabanın üzerinde kule olarak yükselmesiyle bölgede dikkat çekicidir. Podyum tabanda kongre mekanları, kulede konaklama mekanları yer almaktadır. Kule dikdörtgen plan şemasına sahiptir ve yatak odaları plan tipolojisi çift taraflı kullanıma sahip olduğundan oda sayısının maksimum olması sağlanmıştır. Hilton Bursa da bodrum katta kongre mekanları yer alırken, konaklama mekanları üçgen planlı bir kule olarak yükselmektedir. Ancak kule formlu yapılarda çekirdek (merdivenler ve islak hacimler) genellikle ortada konumlandırılır. Oda sayısı arttıkça kütle ve çekirdeğin kapladığı yer artar. Dolayısıyla bu tip yapılarda oda sayısı kısıtlı olmaktadır. Hilton'da plan düzleminde üçgen kule ve çekirdek formundan kaynaklı alan kayıpları görülmektedir. Ancak otel kütle ve cephe tasarımı bakımından modern mimariyi yansıtarak, kule formuyla yatak odalarında Bursa şehir manzarasını izlemeye olanak sunmuştur. 
Tablo 2. Analiz edilen otellerin mimari tasarım özelliklerinin karşılaştırılması

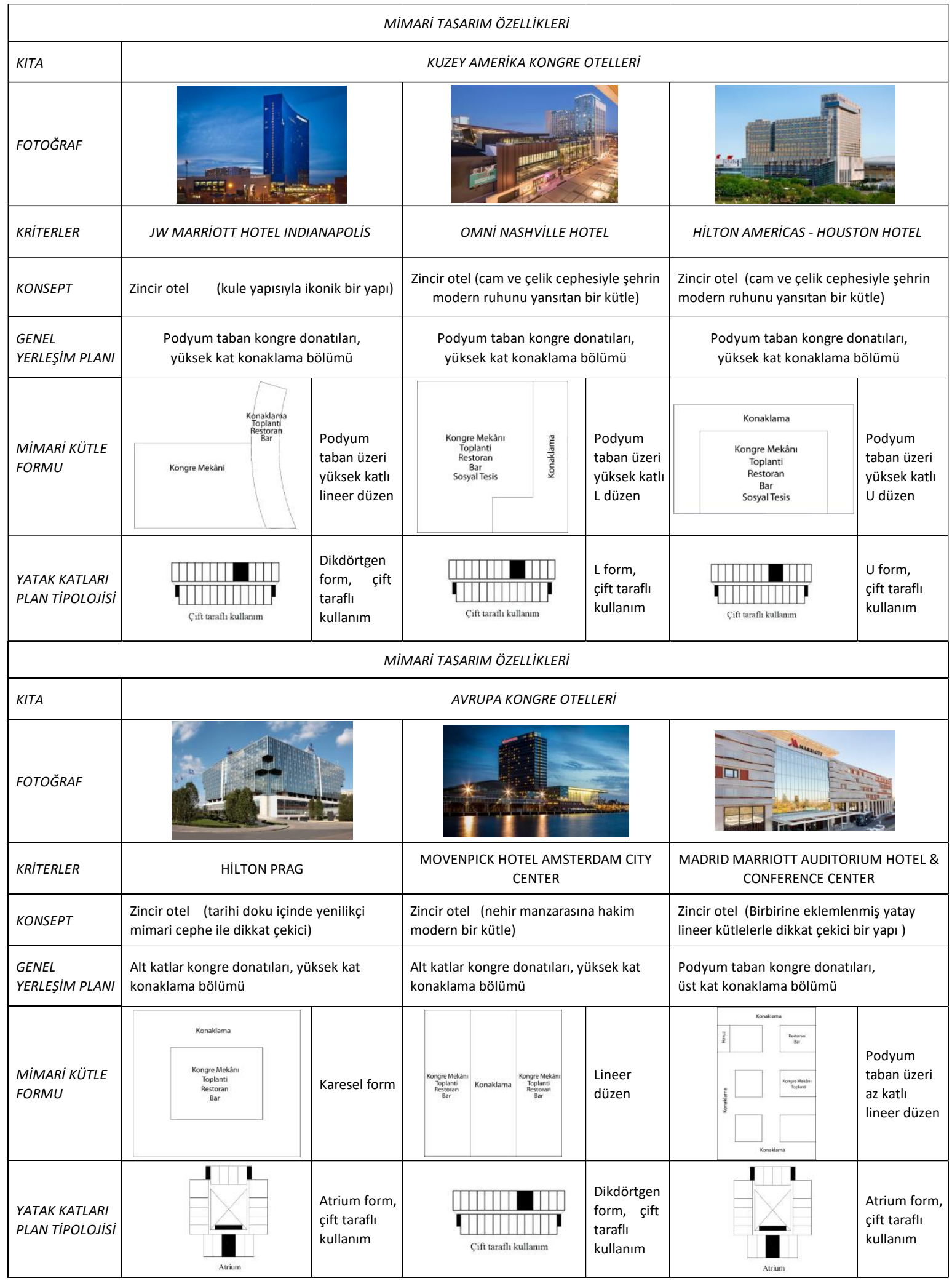

The Importance of Accomodation in Convention Tourism: The Design Criteria and Spatial Standards of Convention Hotels 
Tablo 2. Analiz edilen otellerin mimari tasarım özelliklerinin karşılaştıılması (devamı)

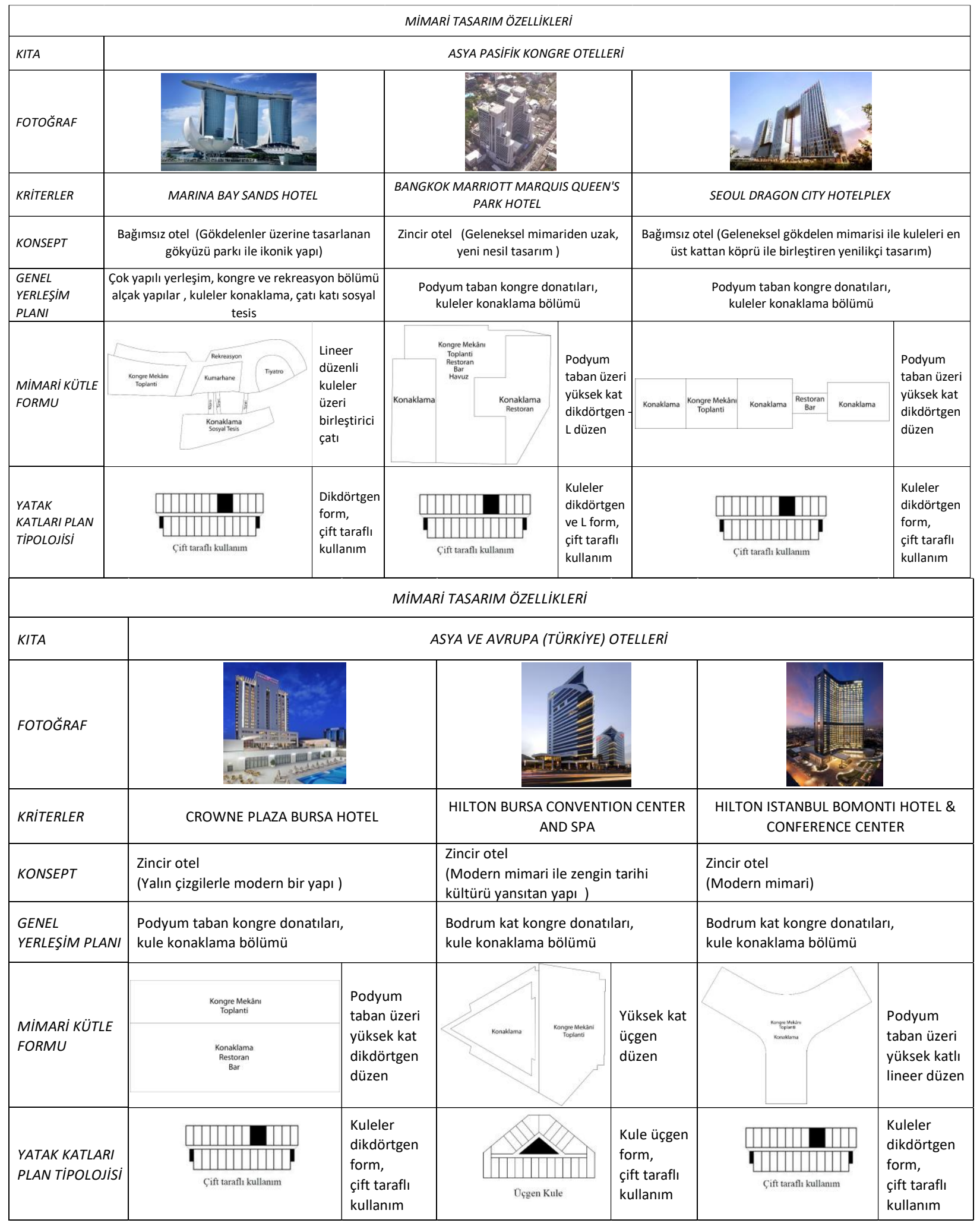

The Importance of Accomodation in Convention Tourism: The Design Criteria and Spatial Standards of Convention Hotels 


\subsection{Mekansal Kurgu Özelliklerinin Değerlendirilmesi}

Mekansal kurgu açısından örnek otellerde özellikle girişler, genel mekanlar, konaklama mekanları ve kongre mekanları değerlendirilmiştir. Girişler açısından incelenen on iki otelden altı otelin konaklama ve kongre girişleri ayrıdır. Tüm otellerde konaklama girişinden kongre mekanına ulaşmak mümkündür. Bütün otellerde servis girişi ayrı planlanmıştır. Bursa'da Crowne Plaza'da konaklama ve kongre girişi aynı kapıdan, servis girişi farklı kapıdan sağlanmaktadır. Otelde genel mekanlar olarak; lobide resepsiyon, kafe, mağaza, konaklama ve kongre mekanlarına çıkan çekirdek bulunmaktadır. Hilton Bursa'da da konaklama ve kongre girişi aynı kapıdan, servis girişi farklı kapıdan sağlanmaktadır. Otelde genel mekan olarak; lobide resepsiyon, kafe, restoran, mağazalar, konaklama ve kongre mekanlarına çıkan çekirdek bulunmaktadır.

Kongre mekan seçiminde diğer önemli role sahip olan genel mekanlardan spa alanı on bir otelde mevcuttur, on otelde havuz bulunmaktadır ve yedi otelde de fitness salonu vardır (Tablo 3). Bursa'da Crowne Plaza'da havuz, fitness salonu, spa bulunmakta, Hilton Bursa da ise spa ve havuz bulunurken, fitness alanı mevcut değildir.

Konaklama mekanları açısından incelenen on otelde odalar kulelerde bulunmakta olup, oda tipleri çeşitlilik göstermektedir. Tüm otellerde suit oda mevcuttur. Bazı otellerde tek kişilik oda tasarlanmamıştır. Ancak tek kişilik odaların kongre katılımcıları tarafından daha çok tercih edilebileceği düşünülerek tasarlanması gerekir. Tüm otelleri karşılaştırırsak sekiz otelde çift kişilik oda daha fazladır. Bursa'da Crowne Plaza' da çift kişilik oda sayısı daha fazla iken, Hilton Bursa' da tek kişilik oda sayısı daha fazladır.

Kongre mekanları açısından incelenen otellerin sadece iki tanesinde kongre ve balo salonu ayrıdır, yedi otelde sergi alanı bulunmamaktadır, on otelde de dinlenme odası mevcut değildir. Bursa'daki iki otelde de çalışma odası, çalıştay salonu, sergi salonu ve dinlenme odası bulunmaktadır. Kongre ve balo salonu ise birlikte kullanılmaktadır.

İncelenen otellerde ana giriş ve kongre mekanları girişinin ayrı olmasının değerlendirildiği erişim kolaylığı kriteri altı otelde sağlanmış, altı otelde sağlanamamıştır. Bursa'daki oteller de ana giriş ve kongre girişi farklı olmadığı için bu kriter eksiktir. Kompaktlık kriteri dokuz kongre otelinde olumlu, üç kongre otelinde olumsuz olurken, Bursa'daki otellerde bu kriter sağlanmıştır. Düzenlilik netlik, esneklik ve karma işlevsellik kriterleri tüm kongre otellerinde ve Bursa'daki otellerde sağlanmıştır. Mekansal zenginlik kavramı altı kongre otelinde ve Bursa' daki iki otelde sağlanmış, dört kongre otelinde sağlanamamıştır. Kongre mekanının dışardan algılanması, kullanıcıların kongre mekanının girişini rahatça bulmalarına göre değerlendirilen okunabilirlik kavramı altı kongre otelinde sağlanırken, Bursa'daki otellerde bu kavram sağlanamamıştır (Tablo 4).

Tablo 4. Analiz edilen otellerde kongre mekanı tasarım kriterlerinin karşılaştırılması

\begin{tabular}{|c|c|c|c|c|c|c|c|c|c|c|c|c|}
\hline \multicolumn{13}{|c|}{ KONGRE OTELLERINDE KONGRE MEKÂNI TASARIM KRITERLERI KARŞLASŞTIRMASI } \\
\hline KAVRAMLAR OTELLR & $\begin{array}{c}\text { JW MARRIOTT } \\
\text { HOTEL } \\
\text { INDIANAPOLIS }\end{array}$ & $\begin{array}{l}\text { OMNI } \\
\text { NASHVILLE } \\
\text { HOTEL }\end{array}$ & \begin{tabular}{|l} 
HILTON \\
AMERICAS \\
HOTEL
\end{tabular} & $\begin{array}{l}\text { HLTON PRAG } \\
\text { HOTEL }\end{array}$ & \begin{tabular}{|l} 
MOVENPICK \\
AMSTERDAM \\
CITY CENERER \\
HOTEL
\end{tabular} & \begin{tabular}{|c|} 
MADRID \\
MARRIOTT \\
AUDITORIUM \\
HOTER\& \\
CONFERENCE \\
CENTER \\
\end{tabular} & \begin{tabular}{|c} 
MARINA BAY \\
SANDS HOTTLL \\
SINGAPORE \\
\end{tabular} & \begin{tabular}{|l} 
BANGKOK \\
MARRIOTT \\
MARQUIS \\
QUEEN'S \\
PARK HOTEL
\end{tabular} & \begin{tabular}{|c} 
SEOUL \\
DRAGON \\
CITY \\
HOTELPLEX
\end{tabular} & \begin{tabular}{|c} 
CROWNE \\
PLAZA BUUSA \\
HOTEL
\end{tabular} & $\begin{array}{c}\text { HILTON BURSA } \\
\text { CONVENTION } \\
\text { CENTER AND } \\
\text { SPA }\end{array}$ & \begin{tabular}{|c|} 
HILTON \\
ISTANBUL \\
BOMONTi \\
HOTEL \& \\
CONERENCE \\
CENTER \\
\end{tabular} \\
\hline ERIŞSM KOLAYLIĞI & $\checkmark$ & $\mathbf{x}$ & $\checkmark$ & $\checkmark$ & $\checkmark$ & $\checkmark$ & $\checkmark$ & $\mathbf{x}$ & $\mathbf{x}$ & $x$ & $\mathbf{x}$ & $x$ \\
\hline KOMPAКТLIK & $\checkmark$ & $\checkmark$ & $\checkmark$ & $\mathbf{x}$ & $\checkmark$ & $\mathbf{x}$ & $\checkmark$ & $\mathbf{x}$ & $\checkmark$ & $\checkmark$ & $\checkmark$ & $\checkmark$ \\
\hline DÜZENLILIK NETLIK & $\checkmark$ & $\checkmark$ & $\checkmark$ & $\checkmark$ & $\checkmark$ & $\checkmark$ & $\checkmark$ & $\checkmark$ & $\checkmark$ & $\checkmark$ & $\checkmark$ & $\checkmark$ \\
\hline MEKANSAL ZENGINLIK & $x$ & $x$ & $\checkmark$ & $\checkmark$ & $\checkmark$ & $\checkmark$ & $\checkmark$ & $x$ & $\checkmark$ & $\checkmark$ & $\checkmark$ & $x$ \\
\hline KARMA ISLLEVSELLIK & $\checkmark$ & $\checkmark$ & $\checkmark$ & $\checkmark$ & $\checkmark$ & $\checkmark$ & $\checkmark$ & $\checkmark$ & $\checkmark$ & $\checkmark$ & $\checkmark$ & $\checkmark$ \\
\hline OKUNABILIRLLKK & $\checkmark$ & $\mathbf{x}$ & $\checkmark$ & $\checkmark$ & $\checkmark$ & $\checkmark$ & $\checkmark$ & $\mathbf{x}$ & $\mathbf{x}$ & $\mathbf{x}$ & $\mathbf{x}$ & $\mathbf{x}$ \\
\hline ESNEKLIK & $\checkmark$ & $\checkmark$ & $\checkmark$ & $\checkmark$ & $\checkmark$ & $\checkmark$ & $\checkmark$ & $\checkmark$ & $\checkmark$ & $\checkmark$ & $\checkmark$ & $\checkmark$ \\
\hline$\sqrt{ }$ & \multirow{2}{*}{\multicolumn{12}{|c|}{$\begin{array}{l}\text { ifadesi incele } \\
\text { ifadesi incel }\end{array}$}} \\
\hline $\mathbf{x}$ & & & & & & & & & & & & \\
\hline
\end{tabular}


Tablo 3. Analiz edilen otellerin mekansal özelliklerinin karşıllaştırılması

\begin{tabular}{|c|c|c|c|c|c|c|c|}
\hline \multicolumn{8}{|c|}{ MEKÂNSAL KURGU ÖZELLIKLERI } \\
\hline \multirow[b]{2}{*}{$\begin{array}{l}\text { OTELIN ALT } \\
\text { MEKÂNLARI }\end{array}$} & \multirow[b]{2}{*}{ TANIM } & \multicolumn{3}{|c|}{ KUZEY AMERIKA KONGRE OTELLERI } & \multicolumn{3}{|c|}{ AVRUPA KONGRE OTELLERI } \\
\hline & & $\begin{array}{c}\text { JW MARRIOTT } \\
\text { HOTEL } \\
\text { INDIANAPOLIS }\end{array}$ & $\begin{array}{c}\text { OMNI } \\
\text { NASHVILLE } \\
\text { HOTEL }\end{array}$ & $\begin{array}{c}\text { HILTON } \\
\text { AMERICAS - } \\
\text { HOUSTON } \\
\text { HOTEL }\end{array}$ & HILTON PRAG & $\begin{array}{l}\text { MOVENPICK } \\
\text { HOTEL } \\
\text { AMSTERDAM } \\
\text { CITY CENTER }\end{array}$ & $\begin{array}{c}\text { MADRID } \\
\text { MARRIOTT } \\
\text { AUDITORIUM } \\
\text { HOTEL \& } \\
\text { CONFERENCE } \\
\text { CENTER }\end{array}$ \\
\hline GiRişLER & $\begin{array}{l}\text { Konaklama } \\
\text { ve kongre } \\
\text { girişinin ayrı } \\
\text { olması }\end{array}$ & $\begin{array}{c}\text { Ana giriş, } \\
\text { kongre ve servis } \\
\text { girişi }\end{array}$ & Tek giriş & $\begin{array}{l}\text { Ana giriş, } \\
\text { kongre ve } \\
\text { servis girişi }\end{array}$ & $\begin{array}{c}\text { Ana giriş, } \\
\text { kongre girişi }\end{array}$ & $\begin{array}{c}\text { Ana giriş, } \\
\text { kongre girişi }\end{array}$ & $\begin{array}{l}\text { Ana giriş, } \\
\text { kongre ve } \\
\text { grup girişi, } \\
\text { yükleme girişi }\end{array}$ \\
\hline $\begin{array}{l}\text { GENEL } \\
\text { MEKÂNLAR }\end{array}$ & $\begin{array}{l}\text { Spa, havuz, } \\
\text { fitness } \\
\text { bulunması }\end{array}$ & $\begin{array}{l}\text { Spa ve kapalı } \\
\text { havuz }\end{array}$ & $\begin{array}{l}\text { Spa, } \\
\text { havuz, } \\
\text { fitness }\end{array}$ & $\begin{array}{l}\text { Spa, fitness, } \\
\text { güzellik } \\
\text { salonu }\end{array}$ & $\begin{array}{l}\text { Spa ve kapalı } \\
\text { havuz }\end{array}$ & $\begin{array}{l}\text { Spa, güzellik } \\
\text { salonu }\end{array}$ & Fitness, havuz \\
\hline $\begin{array}{l}\text { KONAKLAMA } \\
\text { MEKÂNLARI }\end{array}$ & $\begin{array}{l}\text { Otellerin } \\
\text { oda tipleri } \\
\text { tercihi }\end{array}$ & Çift kişilik & Tek kişilik & Çift kişilik & Çift kişilik & Çift kişilik & Çift kişilik \\
\hline \multirow{4}{*}{$\begin{array}{l}\text { KONGRE } \\
\text { MEKÂNLARI }\end{array}$} & $\begin{array}{l}\text { Kongre ve } \\
\text { balo } \\
\text { salonunun } \\
\text { ortak } \\
\text { kullanılma } \\
\text { durumu }\end{array}$ & $\begin{array}{l}\text { Kongre ve balo } \\
\text { salonu ayrı } \\
\text { bulunmakta }\end{array}$ & $\begin{array}{l}\text { Birlikte } \\
\text { kullanım }\end{array}$ & $\begin{array}{l}\text { Birlikte } \\
\text { kullanım }\end{array}$ & $\begin{array}{l}\text { Birlikte } \\
\text { kullanım }\end{array}$ & Yok & $\begin{array}{l}\text { Birlikte } \\
\text { kullanım }\end{array}$ \\
\hline & $\begin{array}{l}\text { Otellerin } \\
\text { diğer } \\
\text { salonları } \\
\text { (çalışma } \\
\text { odası, } \\
\text { çalıştay } \\
\text { salonu vs. ) } \\
\text { bulunma } \\
\text { durumu }\end{array}$ & Yok & $\begin{array}{l}\text { Toplantı } \\
\text { salonları } \\
\text { ile ortak } \\
\text { kullanım }\end{array}$ & Yok & $\begin{array}{l}\text { Toplantı } \\
\text { salonları ile } \\
\text { ortak } \\
\text { kullanım }\end{array}$ & Yok & $\begin{array}{l}\text { Ayri salonlar } \\
\text { mevcut }\end{array}$ \\
\hline & Sergi salonu & Yok & $\begin{array}{l}\text { Toplantı } \\
\text { salonları } \\
\text { ile ortak } \\
\text { kullanım }\end{array}$ & Yok & $\begin{array}{l}\text { Toplantı } \\
\text { salonları ile } \\
\text { ortak } \\
\text { kullanım }\end{array}$ & Yok & Var \\
\hline & $\begin{array}{l}\text { Dinlenme } \\
\text { odası }\end{array}$ & Yok & Yok & Var & Yok & Yok & Var \\
\hline
\end{tabular}


Tablo 3. Analiz edilen otellerin mekansal özelliklerinin karşılaştırılması (devamı)

\begin{tabular}{|c|c|c|c|c|c|c|c|}
\hline \multicolumn{8}{|c|}{ MEKÂNSAL KURGU ÖZELLIKLERI } \\
\hline \multirow[b]{2}{*}{$\begin{array}{l}\text { OTELIN ALT } \\
\text { MEKÂNLARI }\end{array}$} & \multirow[b]{2}{*}{ TANIM } & \multicolumn{3}{|c|}{ ASYA PASIFIK KONGRE OTELLERI } & \multicolumn{3}{|c|}{ ASYA VE AVRUPA (TÜRKIYE) OTELLERI } \\
\hline & & $\begin{array}{l}\text { MARINA BAY } \\
\text { SANDS HOTEL }\end{array}$ & $\begin{array}{c}\text { BANGKOK } \\
\text { MARRIOTT } \\
\text { MARQUIS } \\
\text { QUEEN'S } \\
\text { PARK HOTEL }\end{array}$ & $\begin{array}{c}\text { SEOUL } \\
\text { DRAGON } \\
\text { CITY } \\
\text { HOTELPLEX }\end{array}$ & $\begin{array}{c}\text { CROWNE } \\
\text { PLAZA } \\
\text { BURSA } \\
\text { HOTEL }\end{array}$ & $\begin{array}{c}\text { HILTON } \\
\text { BURSA } \\
\text { CONVENTION } \\
\text { CENTER AND } \\
\text { SPA }\end{array}$ & $\begin{array}{c}\text { HILTON } \\
\text { ISTANBUL } \\
\text { BOMONTI } \\
\text { HOTEL \& } \\
\text { CONFERENCE } \\
\text { CENTER }\end{array}$ \\
\hline GIRIŞLER & $\begin{array}{l}\text { Konaklama } \\
\text { ve kongre } \\
\text { girişinin ayrı } \\
\text { olması }\end{array}$ & $\begin{array}{l}\text { Konaklama, } \\
\text { kongre, } \\
\text { tiyatro, } \\
\text { kumarhane } \\
\text { girişi }\end{array}$ & $\begin{array}{l}\text { Ana giriş, } \\
\text { servis girişi }\end{array}$ & Tek giriş & $\begin{array}{l}\text { Ana giriş, } \\
\text { servis } \\
\text { girişi }\end{array}$ & $\begin{array}{l}\text { Ana giriş, } \\
\text { servis girişi }\end{array}$ & $\begin{array}{l}\text { Ana giriş, } \\
\text { servis girişi }\end{array}$ \\
\hline $\begin{array}{l}\text { GENEL } \\
\text { MEKÂNLAR }\end{array}$ & $\begin{array}{l}\text { Spa, havuz, } \\
\text { fitness } \\
\text { bulunması }\end{array}$ & $\begin{array}{l}\text { Spa, fitness, } \\
\text { güzellik } \\
\text { salonu, havuz }\end{array}$ & $\begin{array}{l}\text { Havuz, } \\
\text { fitness, spa }\end{array}$ & $\begin{array}{l}\text { Fitness } \\
\text { salonu, golf } \\
\text { salonu, } \\
\text { kapalı } \\
\text { havuz, yoga } \\
\text { - pilates } \\
\text { salonu ve } \\
\text { spa }\end{array}$ & $\begin{array}{l}\text { Havuz, } \\
\text { fitness } \\
\text { salonu, } \\
\text { spa }\end{array}$ & $\begin{array}{l}\text { Spa ve kapalı } \\
\text { havuz }\end{array}$ & $\begin{array}{l}\text { Spa ve kapalı } \\
\text { havuz }\end{array}$ \\
\hline $\begin{array}{l}\text { KONAKLAMA } \\
\text { MEKÂNLARI }\end{array}$ & $\begin{array}{l}\text { Otellerin } \\
\text { oda tipleri } \\
\text { tercihi }\end{array}$ & Çift kişilik & Çift kişilik & Tek kişilik & Çift kişilik & Tek kişilik & Tek kişilik \\
\hline \multirow{4}{*}{$\begin{array}{l}\text { KONGRE } \\
\text { MEKÂNLARI }\end{array}$} & $\begin{array}{l}\text { Kongre ve } \\
\text { balo } \\
\text { salonunun } \\
\text { ortak } \\
\text { kullanılma } \\
\text { durumu }\end{array}$ & $\begin{array}{l}\text { Kongre ve } \\
\text { balo salonu } \\
\text { ayrı } \\
\text { bulunmakta }\end{array}$ & $\begin{array}{l}\text { Birlikte } \\
\text { kullanım }\end{array}$ & $\begin{array}{l}\text { Birlikte } \\
\text { kullanım }\end{array}$ & $\begin{array}{l}\text { Birlikte } \\
\text { kullanım }\end{array}$ & $\begin{array}{l}\text { Birlikte } \\
\text { kullanım }\end{array}$ & $\begin{array}{l}\text { Birlikte } \\
\text { kullanım }\end{array}$ \\
\hline & $\begin{array}{l}\text { Otellerin } \\
\text { diğer } \\
\text { salonları } \\
\text { (çalışma } \\
\text { odası, } \\
\text { çalıştay } \\
\text { salonu vs. ) } \\
\text { bulunma } \\
\text { durumu }\end{array}$ & $\begin{array}{l}\text { Toplantı } \\
\text { salonları ile } \\
\text { ortak } \\
\text { kullanım }\end{array}$ & $\begin{array}{l}\text { Toplantı } \\
\text { salonları ile } \\
\text { ortak } \\
\text { kullanım }\end{array}$ & Yok & Yok & Yok & $\begin{array}{l}\text { Toplantı } \\
\text { salonları ile } \\
\text { ortak } \\
\text { kullanım }\end{array}$ \\
\hline & Sergi salonu & Yok & $\begin{array}{l}\text { Toplantı } \\
\text { salonları ile } \\
\text { ortak } \\
\text { kullanım }\end{array}$ & Yok & Yok & Yok & $\begin{array}{l}\text { Toplantı } \\
\text { salonları ile } \\
\text { ortak } \\
\text { kullanım }\end{array}$ \\
\hline & $\begin{array}{l}\text { Dinlenme } \\
\text { odası }\end{array}$ & Yok & Yok & Yok & Yok & Yok & Yok \\
\hline
\end{tabular}




\subsection{Mekansal Standartların Değerlendirilmesi}

Kongre otelleri tasarlanırken yapılan en büyük hata oda sayısı ile kongre mekanı arasında yanlış orantı yapmaktır. Bir kongre oteli balo salonunun koltuk sayısı, misafir odası sayısının iki katına çıkarılmasıyla hesaplanmaktadır (Rutes ve Penner 1985). Otelde salon bin kiş̧ilik olduğunda genelde iki yüz-üç yüz oda bulunur. Etrafında en az altı yüz-yedi yüz kişinin konaklayacağı bir otel ihtiyacı oluşur. Bunlara ek olarak tek kişilik odalar yanında, iki, üç, dört kişinin aynı odada, ayrı yataklarda konaklayabileceği oda gereksinimleri ortaya çıkar (Eker 2019).

İncelenen on iki otel içinden sekiz tanesi, kongre salonlarının kapasitesinin oda sayısına oranı açısından yetersiz kalmıştır. Bursa'daki otellerde de salon kapasitesine göre oda sayıları yetersizdir. Ayrıca Bursa 2023 yılı için hedef kongre şehirlerinden biri seçildiğinden ihtiyaç daha da artacağı için bu kapasiteler giderek daha yetersiz kalacaktır (Tablo 5).

Tablo 5. Analiz edilen otellerde oda sayısı, kongre salonu kapasitesinin karşılaştırılması

\begin{tabular}{|l|c|c|c|}
\hline \multicolumn{4}{|c|}{ OTELLERIN ODA SAYISI - KONGRE SALONU KAPASITESI KARŞILAŞTIRMASI } \\
\hline OTEL ADI & TOPLAM ODA SAYISI & $\begin{array}{c}\text { EN BÜYÜK SALON } \\
\text { KAPASITESI }\end{array}$ & YORUM \\
\hline JW MARRIOTT HOTEL & 1005 & 4000 kişi & Oda kapasitesi yetersiz \\
\hline OMNI NASHVILLE HOTEL & 800 & 2700 kişi & Oda kapasitesi yetersiz \\
\hline HILTON AMERICAS HOTEL & 1207 & 3900 kişi & Oda kapasitesi yetersiz \\
\hline HILTON PRAG HOTEL & 791 & 1500 kişi & Oda kapasitesi yeterli \\
\hline MOVENPICK AMSTERDAM CITY CENTER HOTEL & 408 & 525 kişi & Oda kapasitesi yeterli \\
\hline MADRID MARRIOTT AUDITORIUM HOTEL\&CONFERENCE CENTER & 869 & 2000 kişi & Oda kapasitesi yetersiz \\
\hline MARINA BAY SANDS HOTEL & 2561 & 9225 kişi & Oda kapasitesi yetersiz \\
\hline BANGKOK MARRIOTT MARQUIS QUEEN'S PARK HOTEL & 1388 & 1230 kişi & Oda kapasitesi yeterli \\
\hline SEOUL DRAGON CITY HOTELPLEX & 1700 & 1972 kişi & Oda kapasitesi yeterli \\
\hline CROWNE PLAZA BURSA HOTEL & 216 & 1200 kişi & Oda kapasitesi yetersiz \\
\hline HILTON BURSA CONVENTION CENTER AND SPA & 187 & 1200 kişi & Oda kapasitesi yetersiz \\
\hline HILTON ISTANBUL BOMONTI HOTEL \& CONFERENCE CENTER & 829 & 3000 kişi & Oda kapasitesi yetersiz \\
\hline
\end{tabular}

İncelenen kongre otelleri ve Bursa'daki oteller, kongre mekanı standartları açısından karşılaştırıldığında, JW Marriott Hotel Indianapolis'in sadece tüm standartları sağladığı görülmüştür. Bursa'da ise Crowne Plaza'nın fuayesi verilen referans alana göre yetersizdir, toplantı salonu alanı ve tavan yüksekliği açısından referans değere uygun olup, kongre salonu tavan yüksekliğini sağlamaktadır. Hilton'da ise gerekli fuaye alanı $\mathrm{m}^{2}$ sine ulaşılamamış, ancak kongre salonu alanı ve tavan yüksekliği ile toplantı salonu alanı ve tavan yüksekliği referans değere uygun bulunmuştur (Tablo 6).

İncelen otellerin sadece iki tanesinde toplam kongre mekanı alan1 $9000 \mathrm{~m} 2$ 'den fazla iken, dört otelde 3000-6000 m2 arasında değişmektedir. Otellerin sadece birinde en büyük kongre salonu alanı $4000 \mathrm{~m} 2$ ve üzerinde, altı otelde 2000 m2'ye kadardır. Yine otellerin sadece birinde altmıştan fazla toplantı salonu varken, sekiz otelde otuz adete kadardır.

Bursa Crowne Plaza'da toplam kongre mekanı yaklaşık $2150 \mathrm{~m}^{2}$ olup dört kattan oluşmaktadır. Kongre mekanında toplam on salon bulunmaktadır. Otelde, bodrum, 1., 2. ve 18. katta olmak üzere toplam dokuz adet toplantı salonu bulunmaktadır. Toplantı salonları büyüklükleri, $41 \mathrm{~m}^{2}$ ile $380 \mathrm{~m}^{2}$ arasında değişmektedir. Salonların fuaye alanları mevcuttur, ancak toplantı salonlarının kendilerine ait ayrı fuayeleri yoktur, ortak olarak kullanmaktadırlar. Fuaye alanı çok küçük olduğu için yetersizdir. Ayrıca kongre ve toplantı salonlarının dört ayrı kata yayılması kullanıcıların organizasyonlar arasında erişim kolaylığına engel olmaktadır. 
Hilton Bursa'da iki katta, bir adet büyük kongre salonu, 10 adet toplantı salonu, iki adet çalışma odası olmak üzere toplam 13 salon bulunmaktadır. Otelde farklı katlarda toplantı salonlarının olması salonlar arasında direkt ilişki kurma ve mekanların okunabilirliği açısından olumsuz olmaktadır. Tüm salonların fuayesi mevcuttur. Otelin tek kongre salonu olan balo salonu bodrum kattadır. Salon, 30,48 m x 28,65 m ölçülerinde olup, 7,3 m yüksekliğinde, toplamda 874 m²'dir. Katılımcı sayısı doğrultusunda en fazla 2 salona bölünebilir. Maksimum kapasite 1200 kişidir. Toplantı salonları büyüklükleri, $45 \mathrm{~m}^{2}$ ile $260 \mathrm{~m}^{2}$ arasında değişmektedir. Çok amaçlı salon, çalıştay salonu, çalışma odaları, dinlenme salonu yoktur, otel bu yönden eksik kalmaktadır.

Tablo 6. Analiz edilen otellerde kongre mekanı standartlarının karşılaştırılması

\begin{tabular}{|c|c|c|c|c|c|c|c|c|c|c|c|c|c|}
\hline \multicolumn{14}{|c|}{ KONGRE MEKÂN INCELEMELERI KARŞILAŞTIRMASI } \\
\hline \multirow[b]{2}{*}{ MEKÂN } & \multirow[b]{2}{*}{ REFERANS } & \multicolumn{3}{|c|}{ KUZEY AMERIKA KONGRE OTELLERI } & \multicolumn{3}{|c|}{ AVRUPA KONGRE OTELLERI } & \multicolumn{3}{|c|}{ ASYA PASIFIK KONGRE OTELLERI } & \multicolumn{3}{|c|}{ ASYA VE AVRUPA (TÜRKIYE) OTELLERI } \\
\hline & & $\begin{array}{l}\text { JW MARRIOTT } \\
\text { HOTEL } \\
\text { INDIANAPOLIS }\end{array}$ & $\begin{array}{c}\text { OMNI } \\
\text { NASHVILLE } \\
\text { HOTEL }\end{array}$ & $\begin{array}{l}\text { HILTON } \\
\text { AMERICAS - } \\
\text { HOUSTON } \\
\text { HOTEL }\end{array}$ & HILTON PRAC & $\begin{array}{l}\text { MOVENPICK } \\
\text { HOTEL } \\
\text { AMSTERDAM } \\
\text { CITY CENTER }\end{array}$ & $\begin{array}{c}\text { MADRID } \\
\text { MARRIOTT } \\
\text { AUDITORIUM } \\
\text { HOTEL \& } \\
\text { CONFERENCE } \\
\text { CENTER }\end{array}$ & $\begin{array}{c}\text { MARINA BAY } \\
\text { SANDS } \\
\text { HOTEL }\end{array}$ & $\begin{array}{l}\text { BANGKOK } \\
\text { MARRIOTT } \\
\text { MARQUIS } \\
\text { QUEEN'S } \\
\text { PARK HOTEL }\end{array}$ & $\begin{array}{c}\text { SEOUL } \\
\text { DRAGON CITY } \\
\text { HOTELPLEX }\end{array}$ & $\begin{array}{c}\text { CROWNE } \\
\text { PLAZA BURSA } \\
\text { HOTEL }\end{array}$ & $\begin{array}{c}\text { HILTON } \\
\text { BURSA } \\
\text { CONVENTION } \\
\text { CENTER AND } \\
\text { SPA }\end{array}$ & $\begin{array}{c}\text { HILTON } \\
\text { ISTANBUL } \\
\text { BOMONTI } \\
\text { HOTEL \& } \\
\text { CONFERENCE } \\
\text { CENTER }\end{array}$ \\
\hline FUAYE & $\begin{array}{l}1 \text { kişi için } \\
0,3-0,5 \\
\mathrm{~m} 2\end{array}$ & $\checkmark$ & $\checkmark$ & $x$ & $\checkmark$ & $\checkmark$ & $\checkmark$ & $\mathbf{x}$ & & - & $\mathbf{x}$ & - & $\checkmark$ \\
\hline $\begin{array}{l}\text { KONGRE } \\
\text { SALONU }\end{array}$ & $\left|\begin{array}{c}1 \text { oda için } \\
3 \mathrm{~m}^{2} \text { kongre } \\
\text { alanı }\end{array}\right|$ & $\checkmark$ & $\mathbf{x}$ & $\checkmark$ & $\mathbf{x}$ & $\mathbf{x}$ & $\mathbf{x}$ & $\mathbf{x}$ & $\mathbf{x}$ & $\mathbf{x}$ & $\checkmark$ & $\checkmark$ & $x$ \\
\hline $\begin{array}{l}\text { TOPLANTI } \\
\text { SALONU }\end{array}$ & $\begin{array}{c}1 \text { kiş min. } \\
0,9 \mathrm{~m} 2\end{array}$ & $\checkmark$ & $\checkmark$ & $\checkmark$ & $\checkmark$ & $\checkmark$ & $\checkmark$ & $\cdot$ & $x$ & $\mathbf{x}$ & $\checkmark$ & $\checkmark$ & $\checkmark$ \\
\hline $\begin{array}{l}\text { KONGRE SALONU } \\
\text { TAVAN } \\
\text { YÜKSEKLIĞi } \\
\end{array}$ & $\begin{array}{c}A>1400 \\
m 2, h \min . \\
6,1 \mathrm{~m} \\
A<1400 \\
\mathrm{~m} 2, \mathrm{hmin} .\end{array}$ & $\checkmark$ & $\checkmark$ & $\checkmark$ & $\checkmark$ & $\mathbf{x}$ & $\checkmark$ & $\checkmark$ & $\mathbf{x}$ & $\checkmark$ & $\checkmark$ & $\checkmark$ & $\checkmark$ \\
\hline $\begin{array}{l}\text { TOPLANTI } \\
\text { SALONU TAVAN } \\
\text { YÜKSEKLIĞI }\end{array}$ & $\mathrm{hmin} .3,3 \mathrm{~m}$ & $\checkmark$ & $\checkmark$ & $x$ & $x$ & $x$ & $\checkmark$ & - & $\checkmark$ & $x$ & $\checkmark$ & $\checkmark$ & $\checkmark$ \\
\hline
\end{tabular}

Özetle, Bursa'daki iki otelin de kongre mekanının, oda sayısı ile doğru orantılı tasarlandığı görülmektedir. Fakat dünyada incelenen diğer otellerle karşılaştırıldığında oda sayılarının çok az olduğu açıktır. Bu otellerin ancak küçük ölçekli kongrelere uygun olduğu söylenebilir. Bu noktada şehirde kongre oteli eksikliği olduğu ve mevcut otellerin kongre işlevini yeterince sağlayamadıkları görülmüştür. Böylece ikinci hipotez doğrulanmıştır.

Çalışma sonucunda 10 kongre oteli (Bursa'dakiler kongre oteli olmadığı için sıralamaya alınmamıştır) konum, mimari tasarım özellikleri, mekansal kurgu ve mekansal standartlar bakımından gerekli kriterleri sağlama durumuna göre şöyle sıralanmıştır:

1. Madrid Marriott Auditorium Hotel \& Conference Center (konum, mimari tasarım, mekansal kurgu özellikleri ve mekansal standartlar bakımından olumludur)

2. JW Marriott Hotel Indianapolis (mimari tasarım özellikleri ve mekansal standartlar bakımından olumludur)

3. Marina Bay Sands Hotel (mimari tasarım özellikleri ve mekansal kurgu özellikleri bakımından olumludur)

4. Hilton Prag (mimari tasarım özellikleri ve mekansal standartlar bakımından olumludur)

5. Hilton Americas - Houston Hotel (mekansal kurgu bakımından olumludur)

6. Mövenpick Hotel Amsterdam City Center (mimari tasarım ve mekansal kurgu özellikleri bakımından olumludur)

7. Omni Nashville Hotel (mimari tasarım özellikleri ve mekansal standartlar bakımından olumludur)

8. Hilton İstanbul Bomonti Hotel \& Conference Center (mimari tasarım özellikleri ve mekansal standartlar bakımindan olumludur)

9. Bangkok Marriott Marquis Queen's Park Hotel (mimari tasarım özellikleri bakımından olumludur)

10. Seoul Dragon City Hotelplex (mimari tasarım özellikleri bakımından olumludur)

Görüldüğü gibi, en çok tercih edilen kongre otellerinden bazılarının gerekli tasarım kriterlerini ve mekansal standartları sağlayamadıkları ortaya çıkmıştır. Bu durumda üçüncü hipotez kısmen doğrulanmıştır. Bu noktada otel tercihinde 
sadece kongre oteli tasarım kriterlerinin ve mekansal standartlarının yeterliliğinin değil, organizatörler ve kullanıcılar açısından otel konumlarının veya konaklama ücretlerinin de etkili olduğu söylenebilir.

\section{SONUÇ:}

Çalışma sonucunda kongre şehirlerinin sahip olması gereken özellikler ve kongre otellerinin taşıması gereken konum, mimari tasarım, mekansal kurgu özellikleri ve mekansal standartlar tanımlanmıştır.

Kongre şehirlerinin taşıması gereken özellikler şu şekilde sıralanabilir:

- Şehirlerarası ve şehir içi ulaşımı kolay olmalıdır.

- Yerel yönetimler kongreler için gerekli alt ve üst yapıyı desteklemelidir.

- Kongre otelleri ve tesisleri yeterli olmalıdır.

- Kongre dışı etkinliklerin yapılabileceği mekanlara sahip olmalıdır.

- Sosyal ve kültürel aktivite çeşitliliği bakımından zengin olmalıdır.

İncelenen kongre otellerinin konum özelliklerinden yola çıkarak şu sonuçlara varılmıştır:

- Ulaşım kolaylığı açısından kongre otelleri şehir merkezinde olmalıdır.

- Kongre otellerinin havaalanına yakın olması da (yaklaşık $20 \mathrm{~km}$ ) avantajdır.

- Toplu taşımayla kolay ulaşılabilir olmalıdır.

- Kongre otellerinde şehrin manzara özelliklerinden faydalanılmalıdır.

İncelenen kongre otellerinin mimari tasarım özelliklerinden yola çıkarak şu sonuçlara varılmıştır:

- Kongre otellerinde kütle formu, kentsel bağlam dikkate alınarak tasarlanmalıdır ve şehirde simgesel bir öğe olarak tasarlanabilir.

- Bağlamsal özellikler, kullanıcı / müşteri beklentileri ve mimarın mesleki yaklaşımı mimari tasarım sürecinde dengeli bir şekilde ele alınmalıdır.

- Kongre otellerinin genel yerleşim planı tasarımında kongre mekanları, erişim kolaylığının sağlanması için podyum tabanda, konaklama mekanları kulelerde tasarlanabilir.

- Plan olarak lineer düzen kullanılarak daha verimli mekanlar tasarlanabilir. Yatak katları plan tipolojisinde oda sayısını olabildiğince arttırmak ve verimli mekanlar oluşturabilmek için dikdörtgen formlar kullanılabilir, odalar da koridorun çift tarafı oda olacak şekilde tasarlanabilir.

- Kongre otelleri cephe tasarımında, otelin bulunduğu yapılı ve doğal çevrenin özellikleri, iklimsel konfor dikkate alınmalıdır. Otelde peyzaj/manzara yönünde şeffaf cepheler tasarlanması uygun olur.

İncelenen kongre otellerinin mekansal kurgu özelliklerinden yola çıarak şu sonuçlara varılmıştır:

- Erişim kolaylığı açısından, kongre otellerinde farklı işlevlere ait girişlerin ayrı olarak tasarlanması gerekir. Özellikle kongre girişi ayrı olmalı, kongre mekanına içeriden erişim için yeterli yatay ve düşey sirkülasyon elemanları düzenlenmelidir.

- Konaklama mekanları açısından farklı kişi sayılarına yönelik farklı nitelikte odalar düzenlenmelidir. Bir, iki, üç, dört kişilik odaların yanında, ayrı yatakların bulunduğu iki kişilik odaların bulunması gerekir

- Hizmet mekanlarının çeşitlendirilmesi, spa, açık-kapalı havuz, fitness salonu gibi mekanlarının yer alması gerekir.

- Kongre mekanları açısından, seminer, çalıştay ve toplantı salonu, çok amaçlı salon ayrı mekanlar olarak tasarlanmalıdir.

- Verimli bir kullanım için kongre ve toplantı salonlarına ait ayrı fuaye alanları tasarlanmalıdır.

- Düzenlenen kongrelerdeki poster sunumları ve sponsorların reklam stantları için sergi alanları tasarlanmalıdır.

- Mekansal kompaktlık açısından kongre mekanındaki bütün salonlar ve bunlara hizmet eden mekanlar yatayda ve düşeyde birbirleriyle yakın ve direkt ilişkide olmalıdır.

- Düzenlilik açısından kongre mekanlarında biçimsel açıdan net alanlar oluşturulmalı, kongre mekanları kolay tefriş edilebilecek şekilde tasarlanmalıdır.

- Mekansal zenginlik açısından, kongre mekanı kendi içinde veya otelin diğer kısımlarıyla, atriumlar, galeriler aracılığıyla, otel dışındaki peyzajla veya manzarayla şeffaf cephelerle görsel ilişki kurmalıdır.

- Farklı etkinliklere hitap eden karma işlevli kongre mekanları için, farklı büyüklükte/yükseklikte çok amaçlı salonlar, fuayeler ve total mekanlar tasarlanmalıdır. 
- Okunabilirlik açısından, kullanıcıların otel içinde kongre mekanına rahatça erişmesi, bu mekanlar arasında yönünü bulabilmesi için net rotalar tanımlanmalıdır.

- Esneklik açısından, salonların ihtiyaç halinde bölünebilmesi için bölme sistemlerine sahip olması, gerektiğinde salonların kat yüksekliklerinin ayarlanabilmesi gerekir Salonun yüksek ve düz tavanlı olması uygundur.

- Amfi tiyatro salon tipinden çok düz salon olması daha kullanışlıdır. Toplantı salonu, toplantının tipine ve katılımcı sayısına göre mobilyalarla değişik şekillerde düzenlenmelidir. Bu düzenler; ' $U$ ' Düzeni, banket düzeni, tiyatro düzeni, sınıf düzeni, masa başı düzenidir (Hoşgeçin ve Bozkaya 1994).

- Konuşmacının konsantrasyonu için salondaki sahne ve salona giriş kapılarının karşılıklı konumda olması gerekir.

- Salonlarla birlikte konuşmacıların hazırlık yapması için çalışma ve dinlenme odaları düzenlenmelidir.

İncelenen kongre otellerinin mekansal standartlarından yola çıkarak şu sonuçlara varılmıştır:

- Kongre otellerinde en az 250 oda olması gerekir. Kongre pazarında yatak sayısından çok oda sayısı önemlidir. Oda sayıları ile kongre mekanı kapasitesi arasındaki orantının doğru kurulması gerekir.

- Restoranların kapasitesi hem konaklayan kişi, hem de kongre katılımcısı sayısı göz önüne alınarak hesaplanmalıdır.

- Kongre ve balo salonları ortak kullanımda olacaksa $\mathrm{m}^{2}$ ve kişi kapasitesi yeterli olmalıdır.

- Seminer ve çalıştay salonu, çalışma ve dinlenme odası, çok amaçlı salonlarda ortak kullanım sağlanacaksa $\mathrm{m}^{2}$ ve kişi kapasiteleri referans değerlere uygun olmalı, ihtiyacı karşılayabilmelidir.

\section{TARTISSMA}

Küresel rekabet turizm sektörünün sürekli gelişmesini sağlarken, insanların turizmden beklentilerinin çeşitlenmesi ve iş seyahatlerinin artması kongre turizmini ön plana çıkarmıştır. Kongre turizminde konaklama açısından kongre otellerinin payı oldukça büyüktür. Bu nedenle kongre otellerinin hem kongre turizmine daha iyi hizmet edebilmek hem de o şehre daha çok kongre çekebilmek için uygun niteliklerde ve standartlarda, güncel gereksinimlere cevap verecek şekilde tasarlanması gerekmektedir. Bu çalışmada, farklı ülkelerde ve kentlerde en çok tercih edilen kongre otelleri incelenerek, kongre otellerinin mekansal standartları ve tasarım kriterleri ortaya konulmuş ve Bursa'nın kongre turizmi açısından potansiyeli irdelenmiştir.

Çalışma kapsamında incelenen otellerin hem içinde bulunduğu şehir açısından kongre turizmi altyapısına sahip olduğu, hem de kongre otellerinin taşıması gereken konum, mimari tasarım, mekansal kurgu özellikleri ve mekansal standartları büyük oranda karşıladığı tespit edilmiştir. Bununla birlikte otel tercihinde sadece kongre oteli tasarım kriterlerinin ve mekansal standartlarının yeterliliğinin değil, organizatörler ve kullanıcılar açısından ekonomik faktörlerin de etkili olduğu görülmüştür.

2023 Türkiye Turizm Stratejisi ve Eylem Planı'nda hedef kongre şehri gösterilen Bursa'nın sahip olduğu potansiyellerle kongre turizmi açısından gerek Türkiye'de, gerekse uluslararası arenada önemli bir şehir olduğu açıktır. Bununla birlikte bu çalışmada şehirde kongre oteli olmadığı, var olan kent otellerinin kongrelerde kullanıldığı, büyük kongrelerde bu otellerin yetersiz kalacağı tespit edilmiştir. Bu noktada Bursa'da kent merkezine yakın, ulaşımın kolay sağlandığı, katılımcı sayısı ile doğru orantılı büyüklükte mekanlara sahip, bu çalışmada belirlenmiş tasarım kriterlerine ve mekansal standartlara uygun kongre otellerinin yapılması gerektiği düşünülmektedir. Şehrin kongre turizmi açısından gelişmesi ve rekabet gücünün artması için nitelikli kongre otellerinin yapılması büyük önem taşımaktadır.

\section{Etik Standart ile Uyumluluk}

Çıkar Çatışması: Yazarlar herhangi bir çıkar çatışmasının olmadığını beyan eder.

Etik Kurul İzni: Bu çalışma için etik kurul iznine gerek yoktur

Finansal Destek: Yoktur. 
Bu makale Doç. Dr. Sibel Polat’ın danışmanlığında Büşra Öztaş’ın yazdığı Bursa Uludağ Üniversitesi Fen Bilimleri Enstitüsü Mimarlık Ana Bilim Dalı’nda tamamlanan “'Kongre Otelleri Standartları ve Tasarım Kriterleri Üzerine Bir Araştırma: Bursa'da Kongre Turizmi Olanakları” adlı yüksek lisans tezi çalışmasından üretilmiştir.

\section{KAYNAKÇA:}

Anonim (1998). 2020 Yilı 1/100.000 Ölçekli Bursa Çevre Düzeni Planı Raporu https://www.bursa.bel.tr/dosyalar/resimler/meclis_imar/105_100000_lekli_plan_deBursa_hkmler_tarm_ve_orman_o nama_snrl_tm_1003_2014onayl.pdf -(Erişim tarihi: 25.01.2021).

Anonim (2017). Turizm verileri. http://www.kulturturizm.gov.tr/Eklenti/2140,turizmverileripdf.pdf?0 -(Erişim tarihi: 09.06.2016).

Anonim (2017a). Turizm istatistikleri. 2020. http://yigm.kulturturizm.gov.tr -(Erişim tarihi: 25.01.2021).

Arber, E. (2008). Türkiye'de Kongre Turizminin Sorunları ve Çözüm Önerilerine Yönelik Bir Alan Araştırması. Doktora Tezi, Ankara: Gazi Üniversitesi, Sosyal Bilimler Enstitüsü, İşletme Anabilim Dalı.

Aymankuy, Y. (2006). Kongre Turizmi ve Fuar Organizasyonları. Ankara: Detay Yayıncılık.

Balıkçıoğlu, G. (2004). Urban Convention Hotel Design Criteria and A Design Proposal for Ankara Case. Yüksek Lisans Tezi, Ankara: Orta Doğu Teknik Üniversitesi, Fen Bilimleri Enstitüsü, Mimarlık Anabilim Dalı.

Doğu, O. (1982). Oteller, Birsen Yayınevi, İstanbul.

Eker, H. (2016). BURKON Turizm \& Kongre Şirketi Genel Müdürü Hasan Eker ile Yapılan Görüşme 1.

Eker, H. (2019). BURKON Turizm \& Kongre Şirketi Genel Müdürü Hasan Eker ile Yapılan Görüşme 2.

Gökdağ Aydıncı, B. (2009). Kent Otellerinde Ortak Kullanım Alanlarının İncelenmesi: Talimhane Bölgesi Örneği. Yüksek Lisans Tezi, İstanbul: Yıldız Teknik Üniversitesi, Fen Bilimleri Enstitüsü, Mimarlık Anabilim Dalı.

ICCA (2017). ICCA Statistics Report Country \& City Rankings Public Abstract, Hollanda.

Karasu, T. (1985). Kongre Turizmi ve Türkiye, Kültür ve Turizm Bakanlığı Eğitim Dairesi Başkanlığı Yayınları, Ankara, 32.

Lawson, F. (1995). Hotels\&Resorts Planning Design and Refurbishment. Butterworth Architecture, 348.

Lawson, F. (2000). Congress, Conveniton\&Exhibition Facilities Planning, Design and Management. Architectural Press, 235pp.

Opak, B. V. (2009). Beş Yıldızlı Kent Otellerinde Lobi Tasarım İlkeleri (İstanbul Örneğinde Bir İnceleme). Yüksek Lisans Tezi, , İstanbul: Yıldız Teknik Üniversitesi, Fen Bilimleri Enstitüsü, Mimarlık Anabilim Dalı.

Öztaş, B. (2019). Kongre Otelleri Standartları ve Tasarım Kriterleri Üzerine Bir Araştırma: Bursa'da Kongre Turizmi Olanakları. Yüksek Lisans Tezi. Bursa Uludağ Üniversitesi, Fen Bilimleri Enstitüsü, Mimarlık Anabilim Dalı.

Pembegül, T. (2009). Assesment of Convention Centers From Users Perspective; Application of Importance Performance Analysis. Yüksek Lisans Tezi, , Ankara: Orta Doğu Teknik Üniversitesi, Fen Bilimleri Enstitüsü, Mimarlık Anabilim Dalı.

Penner, R.H. (1991). Conference Center Planning and Design A Guide for Architects, Designers, Meeting Planners, and Facility Managers. Architectural Design and Technology Press, 256.

Penner, R.H., Adams, L., Robson, S.K.A. (2013). Hotel Design Planning and Development. USA, Canada, 420. 
Peters, P., Erben, C. (1979). Kongre Merkezleri Ve Oteller, Aynak Yayınevi, Ankara.

Rutes, W., Penner, R.H. (1985). Hotel Planning and Design. Whitney Library of Design.

Var, T., Cesario, F., Mauser, G. (1985). Convention Tourism Modelling, Tourism Management, 194-204.

Yetiz Özden A. (2015). Antalya Bölgesinde 1990 ve 2015 Yılları Arasında Yapılan Otellerin Plan Tiplerinin İncelenmesi. Yüksek Lisans Tezi, , Adana: Çukurova Üniversitesi, Fen Bilimleri Enstitüsü, Mimarlık Anabilim Dalı.

Yürek, S. (2007). 20. yüzyıl Başından Günümüze Adana'da Kent Otellerinin Gelişimi. Yüksek Lisans Tezi, Adana: Çukurova Üniversitesi, Fen Bilimleri Enstitüsü, Mimarlık Anabilim Dalı. 